\title{
Agroecology and Field Education: A Necessary Debate
}

\author{
Rafael Rossi \\ Social and Human Sciences Center, Federal University of Mato Grosso do Sul \\ University City CEP 79070-900, Campo Grande - MS, Brazil \\ Tel: 55-673-345-7636 E-mail: r.rossi@ufms.br
}

Received: January 17, 2015 Accepted: March 14, 2015 Published: March 17, 2015

doi:10.5296/elr.v1i1.7246 URL: http://dx.doi.org/10.5296/elr.v1i1.7246

\begin{abstract}
It's essential to spread and strengthen a debate that worry about the links that can be created between the field education and agroecology. Understood as an educational movement that the peasants in the Brazilian case has an important action, the field education is necessarily linked to another model of agricultural development. In this sense, agroecology can be understood as a dynamic indispensable in educational appropriation of peasants process.
\end{abstract}

Keywords: Field education, Agroecology, Agrarian issue, Education 


\section{First Words}

Through this text we have the problematization on order from our operations in the graduation on Field Education at the Federal University of Mato Grosso do Sul - UFMS in Campo Grande - MS, articulating the dialectic appropriate relations between the field education, understood here as a form of popular education, and agroecology. The methodology used in this short text is the literature review with the explanation of inequalities and contradictions inherent in agribusiness in Brazil. This objective is justified, in turn, with the need to clarify the positions and discourses that are based on the reformist perspective and revolutionary praxis. It's like asking: Agroecology and field education should be worked and articulated within the structuring panorama capitalist mode of production? Just some reforms? Or theoretical and practical movement that unveil constantly through critical and practical performance limits of capitalism and point your urgent overcoming is necessary?

The answer is not so obvious and fast ... In public policy, social programs, in the media and in academic debate many propositions are contradictory and "shuffle" in "fads" of the most varied, from "defense" to people from farm to its implicit subordination and indirectly to agricultural development model of agribusiness and therefore the uneven structure, contradictory and perverse capitalism. An example is the ideological propaganda present in the multinational Monsanto site - which engages in the production, distribution and marketing of pesticides and genetically modified seeds - "defending" the sustainability in agriculture: "Sustainable agriculture is the essence of Monsanto. We are committed to developing technologies that enable farmers to produce more and conserve more natural resources that are essential to your success. Produce more. Save more. Improve lives. This is sustainable agriculture. And Monsanto has everything to do with it." We might also remember the slogan of BASF: "For us, sustainable development means aligning economic success with environmental and social responsibility. This will ensure success in our business long-term”. It is no coincidence that every year 03 million people are poisoned with pesticides and more than 220,000 come to die corresponding to 660 deaths per day, 25 deaths per hour (GOMEZ, 2012).

In addition to the effect achievements in terms of public policies and specific legislation, education replaces the field and revalues at present the theoretical framework of popular education through the Pedagogy of the Oppressed. This can be observed from at least two relevant points for discussion: 1) the field education has provided a reflection that extends the working class of understanding beyond the peasants, comprising also: coastal communities, the Maroons, indigenous peoples, family farmers, foragers, artisanal fishermen, caiçaras, caboclos, etc; and 2) the advances in the field educational in all types of education, including higher education, has been the result of pressures exercised by these people, often organized in their social movements, that is, has been the oppressed of the field that are releasing and showing explicitly the whole civil society historical segregation and expropriation that were subordinates.

With regard to point $\mathrm{n} .1$ is important to state that such expansion of the peasant working class concept is only possible because the work, the defense of the territory and solidarity between the peoples allow us to understand geographically (both as immaterial material manner) work 
as a central element in the educability that develop and transmit culturally and also work as the glue of social struggles that mobilize. Thus, the geographical reading of field education, especially in the geography of the area of education, need to appropriate and reflect on popular education and Pedagogy of the Oppressed that is being discussed at present, so that the peasant territory will become even more visible as place of residence, production and transmission of knowledge and active resistance locus and creative of their populations, extolling not only in the academic world the urgent need to think collectively on another agricultural development model that overcomes the agribusiness by empirical evidence of agriculture's ability peasant.

\section{A necessary Debate}

The contradiction is everywhere and it is that we can see the path to an agriculture that produces healthy food and effectively without the exploitation of natural resources and of man by man. Machado and Machado Filho (2014) in his monumental and important work "The dialectic of Agroecology" in explaining, in a manner accessible to the reader unfamiliar with the technical terminology of Agricultural Sciences, the concreteness and practicality of agroecological procedures at every scale with less environmental and economic costs. For decades, conventional agriculture has denied the nature, as the authors argue, and agroecology, in turn, the affirmation of life, so it is the negation of the negation. The same is true of education in the agricultural space, because the elites have always denied the countryside as a place of life, and now, through education of this field of view is denied and more than ever the field is stated as a place of knowledge, culture, life and work. However we must be alert! Agribusiness, which is not dismantled the capital reproduction logic, also comes appropriating this debate the changing and subverting its own logic, however, with all the ideological concern and "masked" as possible. The field education is a movement in Brazil that articulates research in the university and many peasants. The term movement is understood here as a realization of the oppressed pedagogy, that is, developed by the oppressed, in this case, the rural social movements. But also has a connotation that should not be forgotten, that is, the transformative practice of thinking about the world and think about. This provides a collective work prosper and be transmitted from generation to generation within these subjects? Only the broader conception of education allows us to understand the common sense of belonging and engagement in a fight and an ideal. These guys have learned to organize and select the content and their own teaching in the course of their maturation. However, we also learned that it is always necessary to carry out self-criticism of their work. One example is that of the Field Education Movement Pedagogy, do not fight only for conditions that allow the right to education only to people from the field, but also that the state create mechanisms that allow this democratization before the entire working class, because only from it, as we argue throughout the book may appear a truly committed pedagogical practice with the release of every society. No other educational project can thrive in the education field, it does not appear the epistemological and political roots of peasant working class, why is so, we will not be facing the education field, but front to education designed for the field.

So it is with the themes of "family farm" and "sustainable development", for example. And it is these practices that we are terming as reformist perspectives, namely speeches that despite raise some flags historically defended by workers / as, in many cases organized in their social 
movements, do not perform the necessary mediation of criticism pointing to human unsustainability and Environmental capitalism and agribusiness. And it happens for a very clear reason from the point of view of political positioning: large private groups do not intend to reorganize the way to produce social wealth, otherwise, would not continue to be incurred over as the dominant class. An example of this is the fact that acquisitions of properties over 200 ha of groups of large investors in developing countries since 2001, totaling 31 million hectares, could be being used to feed up to 550 million people as shown in research Maria Cristina Rulli and Paolo D'Odorico the Polytechnic University of Milan and the University of Virginia (Note 1).

It happens that this dynamic is a huge potential to be worked and discussed in the educational field and thus the education field displays in their historic struggle that connects land occupations, the camps, settlements, schools etc.; the possibilities to appropriate the knowledge and denied segregated workers to do what Lenin already pointed as a challenge, ie a "concrete analysis of the concrete situation is not the opposite of the theory 'pure', but, rather, it is the culmination of genuine theory, the point where theory meets authentically, in which - for that very reason - becomes praxis". Deny the story or not predisposed to understand it from the point of view of workers / as in the process of re-creation and resistance is a crime and should not be done in the educational experiences in any case!

Therefore, it is worth remembering that: "School education outgrow: rural "school education" in the "field and becomes" the "field. Is linked to a popular democratic project of Brazil and field". (NERY, 1999, p. 06). This allows to understand why the term "field" because "[...] use the expression field, and not the usual rural areas, in order to include [...] a reflection on the current sense of peasant labor and social and cultural struggles of groups living today and try to ensure the survival of this work "(FERNANDES; CERIOLI; CALDART, 1998, p 09.). The education field, has a "uterine" link to social movements struggling for land, with workers / as, with the many occupations to municipal and state departments of education, in short, should not be thought of as a "good deed" the State or an 'inclusive practice" of some companies and private entities.

Silva (2008) addresses of current and lucid way capitalism come to us "forcing in instrumental languages" in a continuous effort to adapt to the market, a conformation of curricula, schools and basically informative content, disconnected and not fight the growing individualism in society globalized. One of the problems present in the development of capitalist relations is that education also happens to be seen in the market logic only as exchange value and not of use. This does not mean that there are no ethical concerns in the educational field, but there is a new appreciation of this as the playback mechanism expanded capital in its expansion and accumulation. However, for this to occur a "social marketing" that embase this ideology is extremely necessary, justifying, in turn, the performance of professional projects designed by private power groups for commonly poor and excluded populations. In the case of peasant populations, conflicts antagonistic educational models and with different perspectives: the first is well disseminated and advocated by several speeches and intends to maintain the subordinate status of the people of the field and the other model is precisely because these people thought and valued in their daily struggles with criticism even 
overcoming of capitalism itself. This conflict, in turn, is linked not only to the educational plan, but also the class struggle in the agrarian question today in a broader perspective.

Mészáros (2008) presents enriching ideas and arguments in the pedagogical reflection by associating social and educational processes. In their view there can be no radical changes in the educational system without, however, having breaks and reforms in control of the capital system. In this regard, education should not worry as only qualify with a view to the labor market, but for life. Education should be an adequate supply to invest in research and teaching strategies to promote the overcoming of alienation process put in place by the capital, where profit, competition, individualism crowned by the logic of "self-made man" become increasingly present in reality transmitted through the dominant ideology.

For the author it is important to appear teaching practices that allow discuss with learners disruptions, and the fundamental changes to the construction of a society without exploitation. Therefore, we believe that the work issue is of grave importance to be reflected, since it is a feature that is present mark in all subjects with which we develop our educational activities. Therefore, we need to understand what is the meaning and feelings present in class when it comes to work for, from their experiences and cultures, we can talk in order to instigate criticism and reflection. We believe in the same direction as the author under discussion here, that education should not be based on mere transfer of knowledge and information, with a view to producing a "student / machine" that is, someone who only has encyclopedic knowledge without reflection some; but one of the primary tasks of education should be to create awareness, where hope becomes completely plausible and palpable, demanding think of another logic of production, another company, other education less exclusive and more democratic, with public policies that qualify it.

Agroecology and field education are not utopian fantasies ... They are practical and theoretical dimensions essential to the social transformation of the existing order. Just as it is a contradiction associate agroecology and pesticides, is also the associate rural education and subjection of the peasants to the capitalist logic, or the various existing projects today that through its partnerships "public-private" end up reinforcing increasingly privatization the various sectors. The revolution will not become effective tomorrow morning! Nor is it necessary to think of a revolutionary perspective.

\section{Conclusion}

The Marxian thought already taught us the need to be radical, to take things by the root, examine the man himself and this must be questioned when faced with the diverse and multiple initiatives, speeches and activities that, under the veil of "inclusion" do not discuss or propose to combat the primary contradiction between capital and labor in capitalism. You need to protect and value the knowledge of the field, because the prehistoric people ate, for example, with more than 1,500 species of plants. Already 150 years ago mankind fed with 3,000 species and today: "Today, 15 species respond to $90 \%$ of plant foods and four crops - corn, wheat, rice and soybeans - account for $70 \%$ of production and consumption" (MACHADO \& Machado Filho, 2014, p. 59). 


\section{Macrothink}

Thus, if the Education alone is not enough in the effective transformation of the specific operating conditions prevailing in the social reality, nor without it no possibility of success at any socialist enterprise reminds us Freire's thought. The Rural Education can be read as Movement Pedagogy as it puts in large, clear areas the hopelessly pedagogical task of consciously critical and active mobilization that does not long deconstruction of social order established for the suppression of an exploiting class by another. Rather, this Movement Pedagogy being developed, explains the urgent need for reflection and realization of a qualitatively different social order of the current, but with a class consciousness in which the release of all can be guaranteed, both dominant as the resisting and, precisely because of this, can only be performed by those who organize and resist centuries of oppression. The peasantry, despite its wide cultural diversity, constitutes historically as social class, but through studies of the authors covered here, we can say that it is a social class under construction and this because their reproduction depends on the social struggles and occupations that develop in different areas of democratization of living conditions and social rights. Thus, the education field is indispensable for the peasant social reproduction in the process of active recreation as a social class. As already explained to us: "The condition of the liberation of laborious class is the abolition of all class, as well as the condition of the release of the third state, the bourgeois order, was the abolition of all states and all orders" (Marx, 1985 p. 160). That is why the discussion of diversity in relation to peasant populations can not do without the consideration that fundamentally address the working class and must be understood as an analytical focus its historical movement in the struggles that play and have played with the national agrarian elites and International and thus articulated the development of the capitalist mode of production.

The reformist perspective does not discuss the structure of capitalism and thus is not radical, no debate and attempts to change the status quo. Already the revolutionary consciousness attempts to understand and changes in society and the capitalist mode of production because perceives the primary contradiction and all other contradictions that they originate: "Thus understood, the practice is the central category of philosophy that conceives it not only as an interpretation of the world, but also as a guide to its transformation. This philosophy is none other than Marxism "(VÁZQUEZ, 1968, p. 05). Thus, we do not surrender to reform the sport court of our public schools to be financed by private business groups; make no mistake before the songs on "university countryman" who claim the lifestyle of the children of farmers attempting to "steal" the garb and sense of country life; we do not use the teaching aids such as book "sacred and updated" which can not be critical and reflect ... not turn our pedagogical meetings in times of collective wail and cosmetic commerce site ... Let's always be certain it doubt is the way, because as Bertolt Brecht reminds us: "Of all things safe, the more secure is the doubt."

\section{References}

Fernandes, B. M., Cerioli, P. R., \& Caldart, R. S. (1998). Por uma educação básica do Campo. Texto-Base da Conferência Nacional. Brasília, DF: Ed. UnB.

Gómes, G. C. (2014). Los agrotóxicos: el nuevo holocausto invisible. 2012. Disponível em:< http://www.surysur.net/2012/12/los-agrotoxicos-el-nuevo-holocausto-invisible/> Último acesso: Set. 2014. 


\section{Macrothink}

Education and Linguistics Research

ISSN 2377-1356 2015, Vol. 1, No. 1

Machado, L. C. P., Machado F., \& Luiz, C. P. (2014). Dialética da Agroecologia Contribuição para um mundo com alimentos sem veneno. 1st ed. São Paulo: Expressão Popular.

Marx, K. (1985). A miséria da filosofia. São Paulo: Ed. Global.

Mészáros, I. (2008). A educação para além do capital. São Paulo: Ed. Boitempo.

Nery, I. J. (1999). Apresentação. In ARROYO, Miguel G., Fernandes, Bernardo M. (Eds.). A educação básica e o movimento social do campo. Brasília-DF: Articulação Nacional Por uma Educação Básica do Campo, vol. 02.

Silva, René Marc da Costa (2008). Cultura Popular e Educação - Salto para o Futuro. SEED, MEC, Brasília - DF.

Vázquez, A. S. (1968). Filosofia da Práxis. Rio de Janeiro: Paz e Terra.

Note 1. Information retrieved from http://www.brasildefato.com.br/node/29016

\section{Copyright Disclaimer}

Copyright reserved by the author(s).

This article is an open-access article distributed under the terms and conditions of the Creative Commons Attribution license (http://creativecommons.org/licenses/by/3.0/). 